\title{
Implementasi Peraturan Daerah (Perda) Nomor 12 Tahun 2008 tentang Retribusi Parkir Kendaraan Kabupaten Jember terhadap Sistem Retribusi Parkir Berlangganan
}

\author{
Musa Hidin ${ }^{1} \&$ Abdul Jabar ${ }^{2}$ \\ ${ }^{1}$ Fakultas Syariah, IAIN Jember. E-mail: musahidinhtn290@gmail.com \\ 2Fakultas Syariah, IAIN Jember. E-mail: abdjabar1777@gmail.com
}

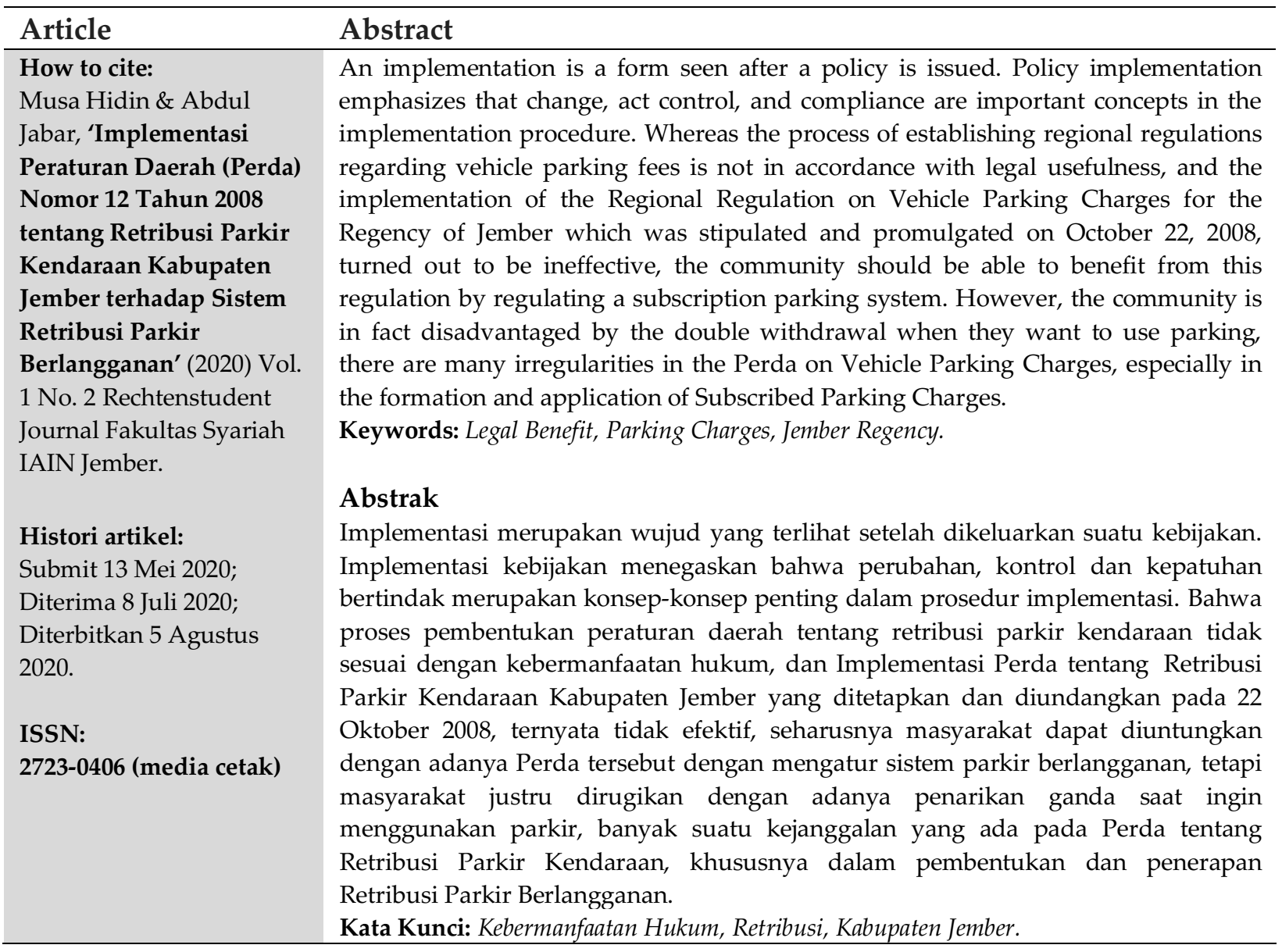

\section{Pendahuluan}

Pembangunan daerah dengan sistem otonomi daerah merupakan bagian yang integral dalam rencana pembangunan nasional yang mendapat perhatian khusus pemerintah pusat sehingga peningkatan kualitas pembangunan di daerah dapat terlaksana dengan baik. Di samping daerah juga mempunyai kewenangan dan tanggung jawab penuh dalam pemenuhan kebutuhan dan kepentingan masyarakat luas di daerahnya berdasar prinsip keterbukaan, partisipatoris dan pertanggungjawaban secara langsung kepada masyarakat. Pemerintah daerah dengan kewenangan otonominya juga bertanggung jawab untuk mengembangkan potensi daerah agar supaya laju pembangunan darahnya berjalan dengan baik sesuai dengan tujuan pembangunan yaitu kesejahteraan masyarakat. 
Untuk mewujudkan cita-cita di atas tentu diperlukan arah kebijakan yang tepat dari pemerintah daerah dalam melaksanakan desentralisasi dan otonomi daerah. Salah satunya dengan meningkatkan pelayanan kepada masyarakat sehingga desentralisasi dan otonomi daerah benar-benar menjadi instrumen mendasar terciptanya kesejahteraan masyarakat, berjalannya proses demokrasi dan keadilan bagi seluruh masyarakat. Implementasi kebijakan otonomi daerah dalam UU No. 23 Tahun 2014 menganut sistem otonomi daerah bertingkat yaitu menempatkan pemerintah provinsi dengan hak otonomi terbatas, pemerintah Kabupaten/Kota dengan hak otonomi luas dan pemerintah desa dengan hak otonomi asli. Sistem tersebut kemudian menempatkan pemerintah daerah sebagai pelaksana dari sistem otonomi daerah.

Kabupaten Jember merupakan daerah yang berada di Provinsi Jawa Timur adalah salah satu daerah yang melaksanakan suatu sistem otonomi daerah dan desentralisasi, dengan dibuktikan adanya suatu kebijakan peraturan, baik yang berupa Peraturan Daerah, Peraturan Bupati dan Keputusan Kepala Daerah yang lainnya yang bersifat hukum demi mengatur masyarakat. Suatu peraturan yang mengikat yang timbul dari pemerintah daerah bertujuan untuk mengatur masyarakat agar lebih baik, begitupun sebaliknya. Peraturan Daerah, atau disingkat dengan Perda, adalah produk kebijakan Pemerintah Daerah yang menurut Undangundang Nomor 23 Tahun 2014 tentang Pemerintahan Daerah, disahkan bersama Bupati dan DPRD dalam sidang Paripurna DPRD, selanjutnya diumumkan dalam Lembaran Daerah. Salah satu Perda yang telah disahkan bersama Bupati dan DPRD dalam Sidang Paripurna DPRD dan telah diumumkan dalam Lembaran Daerah adalah Perda tentang Retribusi Parkir Kendaraan Kabupaten Jember.

Dalam konteks lokal, khususnya di Kabupaten Jember, pada tanggal 10 Oktober 2008 telah ditetapkan dan diundangkan Peraturan Daerah Nomor 12 Tahun 2008 tentang Retribusi Parkir Kendaraan Kabupaten Jember (lembar pengesahan daerah Kabupaten Jember tahun 2008 Nomor 12). Tujuan Peraturan Daerah tentang penyelenggaraan Retribusi Kendaraan tersebut antara lain dijelaskan sebagai berikut "bahwa dalam rangka penertiban dan memperlancar lalu lintas di jalan umum agar pelaksanaan parkir lebih berdaya guna dan berhasil guna dalam memberikan pelayanan kepada pengguna jalan perlu pengaturan parkir kendaraan di Kabupaten Jember"

Sejak ditetapkannya dan diundangkannya Peraturan Daerah Nomor 12 Tahun 2008 tersebut sampai sekarang berlangsung selama kurang lebih 11 tahun. Saatnya sudah mendesak untuk segera di lakukan evaluasi menyangkut bagaimana seharusnya proses pembentukan Perda tersebut dalam sistem good governance, bagaimana Implementasi Peraturan Daerah tersebut sesuai dengan asas Kebermanfaatan Hukum, serta mengimplementasikan dalam Peraturan Daerah tersebut yang mengakibatkan adanya pembayaran secara ganda dalam penggunaan tempat-tempat yang seharusnya sudah mempunyai label berlangganan serta minimnya fasilitas penentuan area parkir yang dianggap area parkir berlangganan, padahal sumbangsih pendapatan dari adanya Retribusi Parkir Kendaraan Kabupaten Jember sangat besar ke daerah. 


\section{Rumusan Masalah}

Adapun rumusan masalah dalam penelitian ini adalah:

1. Apakah Proses Pembentukan Peraturan Daerah Nomor 12 Tahun 2008 tentang Retribusi Parkir Kendaraan Kabupaten Jember sesuai dengan Kebermanfaatan Hukum?

2. Bagaimana Implementasi Peraturan Daerah Nomor 12 Tahun 2008 tentang Retribusi Parkir Kendaraan Kabupaten Jember terhadap Sistem Retribusi Parkir Berlangganan?

\section{Metode Penelitian}

Pendekatan yang digunakan dalam penelitian ini adalah pendekatan Perundangundangan atau Statute Aprroach, yakni pendekatan dengan menggunakan legislasi dan regulasi. Pendekatan undang-undang (statute aprroach) dilakukan dengan menelaah undangundang dan regulasi yang bersangkut paut dengan isu hukum yang sedang ditangani. ${ }^{1}$ Kemudian Pendekatan Sosiologis, yaitu cara mendekati masalah yang akan diteliti berdasarkan semua aturan perundang-undangan yang berlaku, terutama yang mengatur dalam hal Peraturan Daerah. Sedangkan penelitian ini merupakan Penelitian Pustaka (library research), dan Penelitian Studi Kasus (Case Study) sehingga untuk memperoleh penggambaran dan Analisa yang terfokus, maka peneliti menggunakan metode kualitatif deskriptif. Penelitian ini bermaksud untuk meneliti sesuatu secara mendalam yang dimaksudkan untuk mempelajari secara intensif tentang latar belakang masalah keadaan dan posisi suatu peristiwa yang sedang berlangsung saat ini, serta interaksi lingkungan unit sosial tertentu yang bersifat apa adanya.

Dalam penelitian yang akan di teliti oleh peneliti tentang Implementasi Peraturan Daerah (PERDA) Nomor 12 Tahun 2008 tentang Retribusi Parkir Kendaraan Kabupaten Jember Terhadap Sistem Retribusi Parkir Berlangganan ini berlokasikan di Kabupaten Jember, Provinsi Jawa Timur. Kemudian dalam penelitian ini, subjek penelitiannya adalah Dinas Perhubungan Kabupaten Jember, UPT Parkir, Juri Parkir dan Pengguna tempat parkir kendaraan Kabupaten Jember yakni masyarakat Kabupaten Jember.

Untuk memecahkan suatu isu hukum dan memberikan persepsi mengenai apa yang seyogyanya, diperlukan sumber-sumber penelitian hukum. Sumber-sumber penelitian hukum dapat dibedakan menjadi sumber-sumber penelitian yang berupa bahan-bahan hukum primer dan bahan-bahan hukum sekunder. ${ }^{2}$ Dalam penelitian bahan-bahan hukum primer merupakan bahan hukum yang bersifat autoritatif, artinya mempunyai otoritas. Bahan-bahan hukum primer terdiri dari perundang-undangan, catatan-catatan resmi atau risalah dalam pembuatan perundang-undangan dan putusan- putusan hakim. Sedangkan bahan-bahan hukum sekunder berupa semua publikasi tentang hukum yang bukan merupakan dokumendokumen resmi. Publikasi tentang hukum meliputi buku-buku teks, kamus-kamus hukum, jurnal-jurnal hukum dan komentar-komentar atas putusan pengadilan. ${ }^{3}$

Pengumpulan data dalam penelitian ini adalah dengan menggunakan metode Survey book atau library research dilakukan dengan langkah-langkah": a) Menginventarisasi data berupa buku-buku, dokumen dan perundang-undangan yang terkait dengan implementasi pelaksanaan peraturan daerah terhadap sistem retribusi parkir berlangganan. b) Membaca

\footnotetext{
${ }^{1}$ Peter Mahmud Marzuki, Penelitian Hukum (Jakarta: Prenada Media Group, 2005), 97.

2 Peter Mahmud Marzuki, Penelitian Hukum (Jakarta: Prenada Media Group, 2005), 141.

${ }^{3}$ Marzuki, Penelitian Hukum, 141.

${ }^{4}$ Beni Ahmad Saebani, Metode Penelitian Hukum (Bandung, CV Pustaka Setia, 2009), 158.
} 
dan menguraikannya kembali dalam penulisan penelitian. Kemudian melakukan Wawancara dan dengan Dokumentasi. Dalam keabsahan data agar diperoleh temuan yang absah, maka perlu diteliti kredibilitasnya dengan menggunakan teknik-teknik keabsahan data seperti perpanjangan kehadiran peneliti di lapangan, observasi lebih mendalam, dan melacak kesesuaian hasil. Oleh karena itu dalam penelitian ini untuk memperoleh data yang absah peneliti melakukan penerjunan langsung ke lapangan untuk memperoleh data secara mendalam dengan selalu menggunakan perpanjangan penelitian dengan cara membawa Jurnal Penelitian kepada informan yang di dalamnya berisi tanggal penelitian yang selalu dilakukan oleh peneliti sebagai tanda kehadiran peneliti di lapangan. Kemudian melacak kesesuaian hasil dengan cara melakukan penukaran pikiran kepada dosen, maupun dosen pembimbing serta pengecekan data di dalam media internet.

\section{Kesesuaian Pembentukan Peraturan Daerah Nomor 12 Tahun 2008 tentang Retribusi Parkir Kendaraan Kabupaten Jember dengan Kebermanfaatan Hukum}

Kemanfaatan merupakan hal yang paling utama di dalam sebuah tujuan hukum, mengenai pembahasan tujuan hukum terlebih dahulu diketahui apakah yang diartikan dengan tujuannya sendiri dan yang mempunyai tujuan hanyalah manusia akan tetapi hukum bukanlah tujuan manusia, hukum hanyalah salah satu alat untuk mencapai tujuan dalam hidup bermasyarakat dan bernegara. Terkait kemanfaatan hukum ini menurut teori utilistis, ingin menjamin kebahagiaan yang terkesan bagi manusia dalam jumlah yang sebanyakbanyaknya. Pada hakikatnya menurut teori ini bertujuan hukum adalah manfaat dalam menghasilkan kesenangan atau kebahagiaan yang terbesar bagi jumlah orang yang banyak. Pengamat teori ini adalah Jeremy Bentham, teori berat sebelah sehingga Utrecht dalam menanggapi teori ini mengemukakan tiga hal yaitu:

1. Tidak memberikan tempat untuk mempertimbangkan seadil- adilnya hal- hal yang konkret.

2. Hanya memperhatikan hal-hal yang berfaedah dan karena itu isinya bersifat umum.

3. Sangat individualistis dan tidak memberi pada perasaan hukum seorang.

Menurut Utrecht, hukum menjamin adanya kepastian hukum dalam pergaulan manusia. Anggapan Utrecht ini didasarkan atas anggapan vatikan bahwa hukum untuk menjaga kepentingan tiap manusia supaya kepentingan itu tidak dapat diganggu (mengandung pertimbangan kepentingan mana yang lebih besar dari pada yang lain).

\section{a. Tidak memberikan tempat untuk mempertimbangkan seadil-adilnya hal-hal yang konkret}

Dalam pelaksanaan Peraturan Daerah Retribusi Parkir Kendaraan Kabupaten Jember, dengan tujuan bahwa dalam rangka penertiban dan memperlancar lalu lintas di jalan umum agar pelaksanaan parkir lebih berdaya guna dan berhasil guna dalam memberikan pelayanan kepada pengguna jalan perlu pengaturan parkir kendaraan di Kabupaten Jember. Terkait hal diatas bahwasanya memang bagus tujuan pemerintah memberlakukan retribusi parkir kendaraan di Kabupaten Jember, tetapi pemerintah lupa bahwa ada hal-hal yang memang harus dan perlu kiranya untuk di pertimbangkan kembali. Dalam hal ini, kebermanfatan hukum dalam membuat suatu peraturan daerah, dimana cakupannya lebih dekat dengan masyarakat, seharusnya tujuannya juga harus tepat karena lingkupnya juga lebih kecil. Membuat suatu peraturan daerah yang baik dan sesuai dengan kebermanfaatan hukum 
haruslah peraturan daerah tersebut yang partisipatif yang perlu melingkupi baik dari prosesnya maupun substansi peraturan yang bersangkutan, di antaranya adalah:

a. Melingkupi proses bermakna mekanisme dalam pembentukan peraturan perundangundangan harus dilakukan secara transparan sehingga masyarakat dapat berpartisipasi memberikan masukan dalam mengatur suatu persoalan.

b. Mencakup substansi bermakna materi yang akan diatur harus ditujukan bagi kepentingan masyarakat luas, sehingga menghasilkan suatu peraturan perundangundangan yang demokratis serta berkarakter responsif atau populistis (Mahfud MD 1993). ${ }^{5}$

Dengan demikian partisipasi, transparansi dan demokratisasi merupakan suatu kesatuan yang utuh dan tidak dapat dipisahkan dalam pembentukan peraturan perundangundangan di suatu negara demokrasi.

Hal ini bisa disimpulkan bahwa pembentukan Peraturan Daerah Nomor 12 tahun 2008 tentang Retribusi Parkir Kendaraan Kabupaten Jember ini tidak sesuai dengan kebermanfaatan hukum. Karena apabila dilihat dalam pelaksanaannya di lapangan dan jika dilihat pada data diagram di atas, bahwa sebanyak $42,6 \%$ atau setara dengan 43 orang mengetahui adanya Perda Parkir Kendaraan Kabupaten Jember. Lalu sebanyak 34,7\% atau setara dengan 34 orang baru mengetahui adanya Perda Parkir dan sebanyak 22,8\% atau setara dengan 23 orang tidak mengetahui adanya Perda Parkir. Hal dapat dianalisis bahwa, kecenderungan masyarakat Kabupaten Jember masih tidak mengetahui adanya Perda Parkir Kendaraan Kabupaten Jember. Menurut beberapa warga di Jember, "bahwa dalam berjalannya peraturan daerah tersebut saya tidak mengetahui adanya peraturan tentang Retribusi Parkir Kendaraan, yang saya ketahui hanya ketika saya membayar pajak kendaraan bermotor saya, ada tambahan pembayaran yaitu pembayaran Retribusi Parkir Kendaraan berlangganan, dan saya pun tidak mengetahui parkir berlangganan tersebut untuk apa, karena ketika saya parkir di area wilayah Kota Jember, saya juga tetap membayar ketika diminta oleh juru parkir saat itu" ujar Muchtarom. ${ }^{6}$

\section{b. Hanya memperhatikan hal-hal yang berfaedah dan karena itu isinya bersifat umum}

Berbicara konteks Asas Pembentukan Peraturan Perundang-undangan yang baik, dalam pasal 5 UU No. 12 tahun 2011 tentang Pembentukan Peraturan Perundang-undangan pada point "e" yaitu Asas Kedayagunaan dan Kehasilgunaan. Dapat diartikan bahwa Asas Kedayagunaan dan Kehasilgunaan dalam teori Ilmu Perundang-undangan diatas adalah bahwa setiap peraturan perundang-undangan dibuat karena memang benar-benar dibutuhkan dan bermanfaat dalam mengatur kehidupan bermasyarakat, berbangsa dan bernegara.

Kalimat dibutuhkan dan bermanfaat dalam mengatur kehidupan bermasyarakat sepertinya sangat tidak sesuai dengan praktik lapangan yang sudah dijelaskan dalam Perda Retribusi Parkir Kendaraan Kabupaten Jember. Padahal pada Peraturan Daerah tersebut dalam pasal 15 ayat 3 Perda nomor 12 tahun 2008 tentang Retribusi Parkir Kendaraan yang berbunyi "Wajib Retribusi Parkir yang telah membayar Retribusi Parkir Berlangganan, setiap kali

\footnotetext{
${ }^{5}$ Joko Riskiyono, Pengaruh Partisipasi Publik dalam Pembentukan Undang-undang, (Depok: Nadi Pustaka, 2017$), 11$.

${ }^{6}$ Wawancara dengan Ahmad Rojabil, 21 Maret 2020, Alun-alun Kabupaten Jember.
} 
parkir tidak dikenakan lagi pemungutan retribusi parkir, kecuali masa jangka waktu retribusi parkir berlangganan telah habis masa berlakunya". ${ }^{7}$

Dengan adanya hal seperti ini tentu saja masyarakat tidak memperoleh manfaat sekali untuk menikmati hasil pembayaran yang dipungut setiap 1 tahun sekali pada Sistem Administrasi Manunggal di Bawah Satu Atap (SAMSAT) ketika masyarakat melakukan pembayaran pajak Kendaraan Bermotor di Kantor Samsat. Hal yang demikian rasanya sangat tidak adil, karena terjadinya sebuah ketimpangan penerapan hukum yang di kenakan kepada masyarakat oleh pemerintah. Menurut Abdil Furqon, sebagai perwakilan lembaga bantuan hukum konsumen Jember mengungkapkan bahwa: "jika ingin menerapkan peraturan retribusi parkir, pemerintah Kabupaten Jember harus bersikap cepat tanggap terhadap kebijakan ini. Salah satu aspek yang harus diperhatikan adalah persepsi masyarakat terhadap model parkir berlangganan". Abdil menambahkan bahwa: "untuk menjaga kepuasan masyarakat terhadap layanan parkir, pemerintah harus memunculkan standar operasional kerja (SOP) secara ideal, karena yang dipertaruhkan adalah sumber pemasukan dari masyarakat untuk peningkatan pemasukan retribusi". ${ }^{8}$

Oleh karena itu penarikan retribusi parkir secara berlangganan seharusnya diganti dengan pembayaran retribusi secara konvensional saja, yakni dengan membayar secara langsung ketika konsumen atau masyarakat yang memakai jasa parkir yang sudah disediakan, hal ini akan meminimalisir agar tidak terjadi pembayaran ganda. Ataupun jika pemerintah tetap ingin melaksanakan parkir berlangganan, pemerintah dengan dibantu oleh Dinas Perhubungan Kabupaten Jember juga harus memberikan sebuah timbal balik ke masyarakat, yakni dengan mendirikan sebuah palang atau papan pemberitahuan terhadap tempat-tempat yang memang dibuat area parkir berlangganan, sehingga masyarakat dan para Jukir juga mengerti bahwa area tersebut adalah area parkir berlangganan, jikalaupun masyarakat tetap membayar atau memberikan uang, hal tersebut semata-mata karena masyarakat ikhlas untuk memberinya. Dan disisi lain masyarakat pun juga tidak perlu malu atau takut jika tidak memberikan uang kepada jukir, karena memang tempat tersebut adalah area parkir berlangganan. Hal inilah yang seharusnya lebih di fokuskan agar peraturan daerah tersebut tidak bersifat umum saja, namun lebih ke dalam hal-hal yang dirasakan perlu untuk di hadirkan dalam peraturan daerah tersebut.

\section{c. Sangat individualistis dan tidak memberi pada perasaan hukum seorang}

Pembuatan Peraturan Daerah tentang Retribusi Parkir Kendaraan tersebut jika dilihat dalam Naskah Akademik yakni pada konteks Landasan Sosiologis pembentukannya, maka Perda tersebut tidak sesuai dengan kejadian secara empiris atau kejadian di lapangan, karena Perda tersebut bersifat lebih menguntungkan kepada pemerintah dari pada kepada masyarakat. Dalam Landasan Sosiologis yang artinya pertimbangan atau alasan yang menggambarkan bahwa peraturan yang dibentuk untuk memenuhi kebutuhan masyarakat

\footnotetext{
7 Perda Nomor 12 Tahun 2008 tentang Retribusi Parkir Kendaraan Kabupaten Jember

${ }^{8}$ Kahar Haerah, Kontribusi Penerimaan Retribusi Parkir Terhadap Pendapatan Asli Daerah Kabupaten Jember, Jurnal Jurnal Politico Vol 18, No 1 Maret 2018, 105.
} 
dalam berbagai aspek. Landasan sosiologis sesungguhnya menyangkut fakta empiris mengenai perkembangan masalah dan kebutuhan masyarakat dan negara. ${ }^{9}$

Dalam hal ini jika dilihat lagi dalam pasal 4 Peraturan Daerah tentang Retribusi Parkir Kendaraan yang isinya sebagai berikut:

Pasal 4 Retribusi parkir dibedakan menjadi 3 (tiga):

a. Retribusi Parkir Berlangganan adalah retribusi parkir yang dipungut untuk jangka waktu 1 (satu) tahun atau sama dengan masa berlakunya pajak kendaraan bermotor sebagai pembayaran atas penyediaan dan atau pelayanan tempat parkir di tepi jalan umum yang disediakan oleh pemerintah kabupaten.

b. Retribusi Parkir Harian adalah retribusi parkir yang dipungut sebagai pembayaran atas pelayanan penyediaan setiap 1 (satu) kali parkir pada tempat parkir di tepi jalan umum atau tempat lain yang disediakan oleh pemerintah kabupaten.

c. Retribusi Parkir Jalur Panjang adalah retribusi parkir yang dipungut untuk kendaraan di dalam terminal sebagai pembayaran atas pelayanan tempat parkir selain kendaraan penumpang yang dikenakan retribusi atau kendaraan penumpang yang sedang menunggu pemberangkatan.

Pada ayat 1 di lansir pada media Nasional.tempo.co pada Hari Selasa 30 Desember 2008 yakni Kabupaten Jember akan menerapkan parkir berlangganan mulai 1 Januari 200910. Pasal 4 ayat 1 tersebut di dalam pelaksanaannya hingga sekarang masih belum efektif atau tidak sesuai dengan Landasan Sosiologis yang ada pada Naskah Akademik. Pasalnya dalam praktiknya saat ini masyarakat Kabupaten Jember tidak malah diuntungkan dengan adanya peraturan tersebut, tetapi malah di rugikan. Karena praktik di lapangan terjadi suatu pembayaran ganda oleh konsumen.

Di sisi lain pengguna jasa atau masyarakat umum secara sukarela atau terpaksa memberikan uang pembayaran parkir di saat mereka memarkirkan kendaraannya di jalanjalan umum. "Ini bukan masalah pemberian uang parkir secara sukarela atau secara ikhlas saja, mengingat pemerintah Kabupaten Jember dalam Peraturan Daerah tentang Retribusi Parkir Kendaraan juga mengatur pembayaran parkir berlangganan sesuai dengan pajak tahunan kendaraan bermotor. Maka dari itu kami sebagai masyarakat tidak malah diuntungkan, tetapi malah di rugikan. Kemudian jika berbicara masalah keadilan, maka seharusnya terapkan saja penerapan parkir secara konvensional, yakni apa bila pengguna parkir ingin melakukan parkir, maka tarik saja di tempat" paparan dari Marwanto selaku masyarakat Jember. ${ }^{11}$ Hal ini juga belum jelasnya pemerintahan Kabupaten Jember dalam mengatur luas dan ruas parkir kendaraan berlangganan sehingga masyarakat masih membayar uang parkir kepada juru parkir.

Bapak Ony selaku Kepala Dinas Perhubungan Kabupaten Jember saat di wawancarai menyatakan bahwa: "adanya pengaturan Retribusi parkir, baik secara konvensional maupun berlangganan adalah bertujuan untuk meningkatkan PAD (Pendapatan Asli Daerah). Dalam hal ini pemasukan retribusi parkir tersebut dibagi 3, di antaranya Bappeda mendapatkan 13\%, Polres 5\% dan 82\% masuk ke dalam Kas Daerah yang nantinya akan dibuat untuk fasilitas-

\footnotetext{
${ }_{9}^{9}$ Undang-undang Nomor 12 Tahun 2001 tentang Pembentukan Peraturan Perundang-undangan

${ }^{10} \mathrm{https} / /$ nasional.tempo.co/read/153142 diakses pada tanggal 13 Maret 2020

${ }_{11}$ Wawancara dengan Mawarto, 23 Maret 2020, Rumah Mawarto di Kaliwates, Kabupaten Jember.
} 
fasilitas yang ada di daerah"12. Tidak hanya itu, Kepala UPT Sub bagian Tata Usaha juga mengatakan, "bahwa jika anda melihat berita online di www.kissfmjember.com, disitu Kepala UPT Parkir Dinas Perhubungan Kabupaten Jember Bpk. Nanang Budiyanto memaparkan bahwa Retribusi Parkir berlangganan yang ditarik melalui Samsat, tahun 2018 lalu mampu menyumbang PAD sebesar 10,5 Miliar Rupiah. Tetapi memang sangat disayangkan pelayanan parkir di Kabupaten Jember masih perlu adanya perbaikan, salah satunya masih ada aja jukir yang memungut uang parkir". Jika pernyataan tersebut di telaah, maka hal ini tentu saja bertolak belakang dengan realita yang ada. Fasilitas yang dibuat dari anggaran pemasukan terbesar dari retribusi parkir tidak nampak jelas ada.

Sebut saja dalam pembuatan atau pembukaan lahan baru untuk parkir berlangganan. Di Kabupaten Jember masih banyak terdapat parkir liar yang nantinya akan meresahkan masyarakat terhadap penarikannya yang tidak sesuai dengan SOP. Akhirnya banyak masyarakat yang mengeluhkan adanya hal tersebut, seakan-akan masyarakat sudah membayar Retribusi parkir setiap tahunnya, tetapi dalam pelaksanaannya masyarakat tetap akan ditarik oleh para parkir-parkir liar yang awal mula permasalahannya adalah dengan pemerintah yang tidak membuka lahan baru bagi area parkir berlangganan. Tidak hanya itu, masih belum jelasnya tempat-tempat atau penunjukkan area parkir berlangganan, akibatnya masyarakat pun menjadi bingung, di pikirkannya sudah membayar retribusi parkir berlangganan, tapi dalam menentukan area parkir berlangganan saja pemerintah masih belum ada.

\section{Implementasi Peraturan Daerah Nomor 12 Tahun 2008 tentang Retribusi Parkir} Kendaraan Kabupaten Jember terhadap Sistem Retribusi Parkir Berlangganan

\section{a. Teori Implementasi Kebijakan Donald Van Meter dan Carl Van Horn}

Kebijakan merupakan kumpulan keputusan yang diambil seseorang/badan/lembaga yang pada umumnya memegang kekuasaan untuk mengatasi masalah-masalah atau tujuan tertentu, terutama dalam kehidupan bermasyarakat, berbangsa dan bernegara. Publik, artinya hal yang berkenaan dengan masyarakat luas atau umum. Kebijakan publik pada dasarnya adalah kebijakan yang dinyatakan, dikeluarkan, dilakukan ataupun yang tidak dapat dilakukan oleh pemerintah yang memuat program dan kegiatan yang dijalankan. ${ }^{13}$

Teori implementasi kebijakan Van Meter dan Van Horn menegaskan bahwa perubahan, kontrol dan kepatuhan bertindak merupakan konsep- konsep penting dalam prosedur implementasi. Dengan memanfaatkan konsep-konsep tersebut, maka permasalahan yang perlu dikaji ialah jumlah masing-masing perubahan yang akan dihasilkan, dan jangkauan atau lingkup komitmen terhadap tujuan di antara para aktor, atau pihak-pihak yang terlibat dalam proses implementasi. Artinya, implementasi pada program-program kebijakan publik kebanyakan akan berhasil ketika perubahan yang dikehendaki relatif sedikit. Sedangkan komitmen terhadap tujuan, terutama dari mereka yang mengoperasikan program di lapangan, relatif tinggi. Maka antara kebijakan adanya retribusi parkir dan kinerja pemerintah

\footnotetext{
${ }_{12}$ Wawancara dengan Bapak Ony Setiawan S.H selaku Kepala Dinas Perhubungan Kabupaten Jember,13 April 2020, Dinas Perhubungan Kabupaten Jember.

${ }^{13}$ Dadang Sufianto, Pengantar Ilmu Pemerintahan, (Bandung: CV Pustaka Setia, 2015), 97.
} 
dipisahkan oleh sejumlah variabel bebas yang saling berkaitan di antaranya adalah: a) Ukuran dan tujuan Kebijakan, b) Sumber-sumber Kebijakan, c) Ciri-ciri atau karakteristik badan/instansi pelaksana dan d) Komunikasi antar Organisasi terkait dan Kegiatan-kegiatan Pelaksanaan. ${ }^{14}$ Dalam Teori implementasi kebijakan yang baik dari Van Meter dan Van Horn tidak relevan dengan permasalahan adanya retribusi parkir kendaraan dalam sistem retribusi parkir kendaraan berlangganan, dengan analisis sebagai berikut:

\section{Ukuran dan Tujuan Kebijakan}

Kebijakan Retribusi Parkir Berlangganan yang tertuang dalam Peraturan Daerah Kabupaten Jember Nomor 12 tahun 2008 tentang Retribusi Parkir Kendaraan, jika dilihat dan diteliti dalam perda tersebut dan dalam peraturan bupati yang telah dibuat, tidak mencerminkan adanya sebuah ukuran dan tujuan kebijakan. Hal ini sangat terlihat sekali dalam isi Perda tersebut yang tidak membahas masalah tujuan yang signifikan dengan mengadakan sistem retribusi parkir kendaraan, tetapi hanya tujuan umum saja yakni "dalam rangka penertiban dan memperlancar lalu lintas di jalan umum agar pelaksanaan parkir lebih berdaya guna dan berhasil guna dalam memberikan pelayanan kepada pengguna jalan perlu pengaturan parkir kendaraan dan meningkatkan sumber- sumber pendapatan asli daerah lebih signifikan dan lebih intensif." Dengan demikian, lantas apa bedanya dengan pemerintah menerapkan sistem parkir konvensional yang sebelumnya sudah berlaku sebelum adanya Peraturan Daerah tersebut, kan tujuannya juga sama seperti yang di atas.

Lalu dalam Peraturan Bupati Nomor 12 Tahun 2013 tentang Perubahan Peraturan Bupati Jember Nomor 47 tahun 2011 tentang Pelayanan Parkir di Tepi Jalan Umum, dalam peraturan tersebut juga tidak dijelaskan secara signifikan ukuran dan tujuan adanya sistem Retribusi Parkir Berlangganan. Hal inilah yang menyebabkan kemungkinan besar masyarakat Jember dalam data yang diperoleh melalui kuesioner di atas, sebanyak $97 \%$ atau setara dengan 98 orang menginginkan jika Peraturan Daerah tersebut harus segera di evaluasi, karena ukuran dan tujuan adanya sistem parkir berlangganan tidak dijelaskan sedikitpun, baik dalam Peraturan Daerah maupun dalam Peraturan Bupati.

Sesuai dengan teori kebermanfaatan hukum yang ada di atas, bahwasanya suatu produk hukum nantinya pasti akan dijalankan oleh masyarakat, oleh karena itu peraturan yang dibuat seharusnya lebih condong kepada kebermanfaatan masyarakat. Maka dari itu, jikalau pemerintahan Kabupaten Jember ingin menerapkan sebuah sistem Parkir Berlangganan, seharusnya dicantumkan juga ukuran apa yang nantinya akan dicapai dalam penerapan sistem parkir berlangganan dan tujuannya juga untuk apa jika sistem parkir berlangganan itu diterapkan. Maka dengan demikian masyarakat pasti akan tahu dan memahami ukuran dan tujuan adanya sistem parkir berlangganan tersebut.

\section{Sumber-sumber Kebijakan}

Keberhasilan proses implementasi kebijakan sangat tergantung dari kemampuan memanfaatkan sumber daya yang tersedia. Kebijakan menuntut tersedianya sumber daya, baik berupa dana maupun insentif lain. Kinerja kebijakan akan rendah apabila dana yang dibutuhkan tidak tersedia secara memadai. Selain dana, sumber daya manusia merupakan

\footnotetext{
${ }^{14}$ Solichin Abdul Wahab, Analisis Kebijakan dari Formulasi ke Penyusunan Model-model Implementasi Kebijakan Publik, (Jakarta: PT. Bumi Aksara, 2017), 164-165.
} 
sumber daya terpenting dalam proses kebijakan. Sumber daya yang berkualitas akan mendorong keberhasilan kebijakan. Sumber daya manusia memegang peran penting dalam implementasi kebijakan retribusi parkir berlangganan.

Seperti halnya jika berada di lapangan, juru parkir masih kurang mengetahui dan memahami apa itu Peraturan Daerah yang menaungi retribusi parkir khususnya dalam retribusi parkir berlangganan. Dari data kuesioner yang ada di atas, bahwa lebih dari 89,1\% atau setara dengan 90 orang mewakili masyarakat Kabupaten Jember melakukan pembayaran ganda kepada juru parkir. Hal ini karena tidak mempunyai sumber daya manusia dalam hal ini adalah juru parkir untuk bisa memahami peraturan daerah khususnya dalam hal retribusi parkir kendaraan. Akhirnya juru parkir pun seenaknya melakukan pungutan uang parkir. Terlepas dari hal itu, jika kita mengorek lebih dalam lagi, ketidakmampuan juru parkir dalam memahami Peraturan Daerah tersebut khususnya retribusi parkir berlangganan juga disebabkan oleh minimnya pengawasan yang dilakukan oleh Dinas Perhubungan Kabupaten Jember yang dalam hal ini adalah kewenangannya untuk melakukan pengawasan kepada juru parkir.

Juru parkir dalam hal melakukan penarikan uang parkir kepada masyarkat, dikarenakan juga pengawasan dari Dishub (Dinas Perhubungan) yang kurang maksimal, serta fasilitas yang diberikan juga kurang memadai. Contoh saja pemberian palang area parkir berlangganan. Dalam hal ini Dishub masih belum mampu untuk melakukannya, meskipun itu adalah hal sepele, namun manfaatnya sangat berguna sekali. Akhirnya juru parkir juga tidak dapat disalahkan jikalau melakukan penarikan uang parkir, karena Dishub juga tidak bisa memberikan fasilitas yang baik untuk kepentingan juru parkir.

Kemudian sumber daya selanjutnya yang bisa berperan penting dalam keberhasilan implementasi kebijakan adalah masyarakat. Masyarakat juga seharusnya lebih memahami peraturan daerah tersebut agar tidak semena-mena memberikan uang parkir kepada juru parkir. Namun, ada beberapa hal yang tidak boleh menyalahkan masyarakat, dalam data kuisioner diatas bahwa masyarakat Jember masih belum semuanya mengetahui Peraturan Retribusi Parkir Berlangganan. Hal ini juiga disebabkan karena pemerintah dalam hal melakukan sosialisasi kepada masyarakat dianggap masih lemah dan kurang efektif, akhirnya tidak semua masyarakat Jember mengetahui Perda tersebut.

\section{Karakteristik Badan/Instansi Pelaksana}

Karakteristik badan pelaksana di sini mencakup perhatian agen yang terlibat dalam pengimplementasian kebijakan publik. Retribusi Parkir Kendaraan Kabupaten Jember khususnya dalam sistem Retribusi Parkir Berlangganan dinaungi oleh instansi pelaksana Dinas Perhubungan Kabupaten Jember. Mengadakan pembinaan, melakukan pengawasan, memberikan sanksi dan peringatan serta melakukan sosialisasi merupakan solusi yang dikeluarkan oleh Dinas Perhubungan untuk meminimalisir pelanggaran di lapangan. Tetapi sejauh ini apa yang sudah dilakukan oleh Dishub masih belum sesuai dan perlu perbaikan kembali.

Dalam hal melaksanakan peraturan daerah, Dishub masih dirasa tidak sesuai dalam menjalankan tugas, meskipun ada pengawasan, ada pemberian sanksi, tetapi hal itu tidak bisa memberikan efek jerah kepada para juru parkir dalam memungut uang parkir di lapangan. 
Contoh saja ketika masyarakat Jember hendak melakukan parkir di jalan umum pada adanya Car Free Day di alun-alun. Padahal yang digunakan untuk menjadi lahan parkir sementara adalah lahan milik pemerintah, yakni di jalan umum. Banyak sekali hal itu yang menjadi objek pemungutan uang parkir oleh juru parkir yang menggunakan almamater jukir kabupaten Jember. Hal inilah yang seharusnya harus dibenahi oleh instansi pelaksana agar masyarkat juga bisa menikmati fasilitas parkir berlangganan. Oleh karena itu pengawasan, pelaksanaan dan pemberian sanksi yang tegas dan disiplin perlu rasanya ditingkatkan kembali oleh instansi pelaksana agar nantinya memberikan pengaruh yang besar terhadap kualitas pelayanan publik khususnya dalam Parkir Berlangganan.

\section{Komunikasi antar Organisasi Terkait dan Kegiatan-kegiatan Pelaksanaan}

Dalam Teori implementasi kebijakan Van Meter dan Van Horn komunikasi merupakan mekanisme ampuh dari sebuah kebijakan. Apabila koordinasi komunikasi berjalan dengan baik antar implementor maka semakin sedikit peluang pelanggaran di lapangan. Dalam hal ini apabila Pemerintah Daerah, Dinas Perhubungan, Juru Parkir dan masyarakat menjalin komunikasi yang baik dengan bertukar pikiran mengenai apa yang saling diharapkan, maka akan terjalin keharmonisan dan prospek kebijakan yang efektif.

Kenyataan yang berada di lapangan bahwa ada beberapa elemen implementor yang dalam tidak berkoordinasi dengan baik, yakni pada juru parkir. Dinas Perhubungan selaku yang mempunyai kewenangan dalam mengangkat dan memberhentikan juru parkir, masih dirasa tidak berdampak baik. Meskipun Dinas Perhubungan sebelum menerjunkan para juru parkir kelapangan, biasanya juru parkir tersebut mendapatkan diklat terlebih dahulu, yakni terkait pemahaman parkir dan SOP pelaksanaan parkir di Kabupaten Jember. Tetapi semuanya masih dirasa belum efektif untuk berjalan. Dalam hal parkir berlangganan, juru parkir masih tetap saja memungut uang parkir kepada konsumen. Oleh karena itu perlu adanya perbaikan kembali oleh Dishub dengan terus berinovasi untuk membenahi implementor pelaksanaan kebijakan publik yang dalam hal ini adalah para jukir.

\section{b. Teori Maslahah al-Mursalah}

Salah satu dari keistimewaan Hukum Islam adalah bahwa hukum Islam itu diterapkan berdasarkan kemaslahatan manusia. Penalaran ijtihad yang menggunakan corak Marsalah Mursalah atas dasar kemaslahatan yang tidak diakui dan juga tidak ditolak keberadaannya ini banyak terjadi dalam masyarakat, sehingga seorang Mujtahid dituntut untuk menyelesaikan persoalan sebagai upaya pengembangan hukum. Marsalah Mursalah diakui jika berkaitan dengan Maqasid Syariah seperti syarat yang ditetapkan oleh Imam Ghozali, bahwa harus ada kesesuaian diantara keduanya dan maslahah itu harus logis dan bertujuan menghilangkan kesulitan manusia. Masyarakat berkembang selalu mengikuti perkembangan zaman, karena itu untuk mengantisipasi perubahan dan perkembangan masyarakat. Islam datang membawa ajaran dan prinsip dasar yang bisa ditafsirkan dan dikembangkan, agar hukum Islam mampu merespons dan memelihara kemaslahatan hidup masyarakat yang menjadi tujuan syariat Islam. ${ }^{15}$

\footnotetext{
${ }^{15}$ Muhammad Mafruki, Respon Masyarakat Kota Malang Terhadap Peraturan Daerah Kota Malang Nomor 3 Tahun 2015 Tentang Retribusi Jasa Umum Perspektif Maslahah Mursalah, (Malang: Skripsi, 2017), 70.
} 
Sebagaimana telah disebutkan di atas bahwa eksistensi Peraturan Daerah yang menjadi topik dalam penelitian ini akan dikupas menurut asas- asas Maslahah (Kemaslahatan). Ada beberapa syarat yang harus dipenuhi untuk kemaslahatan, yaitu: ${ }^{16}$

1. Adanya persesuaian antara Maslahat yang dipandang sebagai sumber dalil yang terdiri dari tujuan syariat.

2 Maslahat itu harus masuk akal, mempunyai sifat-sifat yang sesuai dengan pemikiran yang rasional, dimana seandainya ditujukan kepada rasionalis akan diterima.

3. Pengguna dalil Maslahat ini dalam rangka menghilangkan kesulitan yang terjadi.

4. Harus benar-benar membuahkan Maslahah (Kemaslahatan).

5. Maslahah itu sifatnya umum, bukan seperti perorangan, maksudnya ialah bahwa dalam kaitan dengan pembentukan hukum atas suatu kejadian atau Maslahah dapat melahirkan kemanfaatan bagi kebanyakan umat manusia yang benar-benar dapat terwujud atau bisa menolak Mudharat.

6. Pembentukan hukum dengan mengambil kemaslahatan ini tidak berlawanan dengan tata hukum atau dasar ketetapan nash dan ijma'.

Dalam teori Maslahah Mursalah yang sudah di paparkan di atas, rasanya dalam pelaksanaan sistem Retribusi Parkir Berlangganan bisa dikatakan tidak relevan. Hal ini didasarkan pada data yang diperoleh di atas, bahwa melalui kuesioner yang disebar peneliti melaui link google form yang menjaring 101 responden yaitu masyarakat jember. Dalam data tersebut terdapat $54,5 \%$ atau setara dengan 55 orang menyatakan bahwa Perda tersebut khususnya sistem Retribusi Parkir Berlangganan kurang efektif, 3,7\% atau setara dengan 35 orang menyatakan tidak efektif dan 10,9\% atau setara dengan 11 orang menyatakan efektif. Alasan kurang efektif, tidak efektif dan efektifnya Perda tersebut diambil dari pertanyaan adanya pembayaran kembali atau pembayaran ganda yang dilakukan oleh masyarakat kepada juru parkir dalam hal parkir berlangganan. Maka jika dipandang menurut Maslahah Mursalah yang mana sejatinya kehidupan manusia seyogianya harus menuju pada suatu kemaslahatan. Dalam Hukum Islam suatu kemudaratan harus ditinggalkankarena akan mempersulit manusia. Seperti salah satu kaidah tentang Maslahah Mursalah :

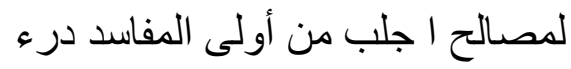

"Menolak kerusakan lebih diutamakan daripada menarik kemaslahatan"

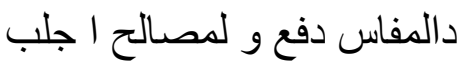

"Meraih Kemaslahatan dan menolak Kemudaratan"

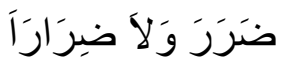

"Tidak memudaratkan dan tidak di mudaratkan"

Maksud dari kaidah ini ialah, kewajiban menghindarkan terjadinya suatu kemudharatan, atau dengan kata lain kewajiban melakukan usaha-usaha preventif agar jangan terjadi satu kemudaratan, dengan segala upaya yang memungkinkan dapat dihilangkan dan dapat menghasilkan kemaslahatan. Maksud yang demikian sesuai dengan dalil-dalil Maslahah Mursalah yang dikenal dikalangan Ulama Ushul.

Dalam teori Maslahah Mursalah terdapat macam Maslahah Mursalah yang dilihat dari segi kandungannya, yaitu Maslahah al- Amanah yang arti dari istilah tersebut ialah kemaslahatan

\footnotetext{
${ }^{16}$ Abdul Wahab Khallaf, Ilmu Ushul Figh, (Semarang: Dina Utama, 1994), 116.
} 
yang bisa mengakomodir semua orang yang artinya untuk semua kepentingan masyarakat akan teapi juga bisa berbentuk kepentingan mayoritas umat. Yang bisa digaris bawahi dalam macam teori ini adalah bahwa Maslahah al-Amanah inilah yang menjadi acuhan bagi manusia dan selalu menjadi tujuan untuk bisa meraih kemaslahatan. Yang kedua ialah Maslahah alKhossoh yang artinya kemaslahatan pribadi dan ini sangat jarang sekali artinya kecil bagi masyarakat untuk mengimplementasikan dari teori tersebut.

Oleh karena itu dari yang dijelaskan diatas bahwa sejalan dengan semangat Hukum Islam dalam mem back-up semua dinamika hukum yang terjadi di tengah-tengah masyarkat, maka Maslahah al- Amanah yang lebih diutamakan dan dilaksanakan. Hasil dari survey kepada 101 orang masyarakat yang ada di Jember bahwa lebih besar terhadap unsur kemudaratan, maka keberadaan Peraturan tersebut yang memuat sistem Retribusi Parkir Berlangganan tidak sejalan artinya harus ada perubahan ke depan demi tercapainya sebuah kemaslahatan. Dalam data yang diperoleh peneliti diatas bahwa, 97\% atau setara dengan 98 orang mengingkan agar Peraturan Daerah tersebut segara di evaluasi dan dibenahi.

\section{Kesimpulan}

Berdasarkan pembahasan pada bab-bab sebelumnya, maka dapat dikemukakan kesimpulan bahwa pembuatan dan pengimplementasian Peraturan Daerah Nomor 12 Tahun 2008 tentang Retribusi Parkir Kendaraan Kabupaten Jember ternyata belum efektif. Secara spesifik kesimpulan ini dapat dirumuskan sebagai berikut:

1. Hal ini memang benar bahwasanya Pemerintah Kabupaten Jember dalam membuat suatu produk hukum terutama tentang Retribusi Parkir Kendaraan Kabupaten Jember, tidak memenuhi pembentukan yang sesuai dengan kebermanfaatan hukum, hanya melibatkan masyarakat sebagai penenteraman saja dalam membuat suatu peraturan daerah tersebut. Karena jika peraturan yang sesuai dengan Kebermanfaatan Hukum, maka peraturan tersebut harus bersifat partisipatif, dengan demikian maka akan tercipta suatu produk hukum yang demikian dengan adanya partisipasi, transparansi dan demokratisasi. Karena produk hukum tersebut nantinya juga akan kembali kepada masyarakat banyak, untuk itu produk hukum yang bersifat partisipatif sangat penting dibutuhkan dalam pembuatan suatu peraturan, khususnya di lingkup daerah. Meskipun Peraturan Daerah Nomor 12 Tahun 2008 tentang Retribusi Parkir Kendaraan Kabupaten Jember sudah sejak 11 tahun yang lalu ditetapkan dan diundangkan, namun masih ditemukan beberapa permasalahan yang terjadi di masyarakat, antara lain: pertama, adanya suatu pembuatan Peraturan Daerah oleh Kabupaten jika dilihat dari Landasan Sosiologis nya yang notabene masyarakat membutuhkan peraturan tersebut untuk dapat diuntungkan dengan adanya fasilitas yang diberikan oleh pemerintah, tetapi dalam Perda tersebut, masyarakat malah dirugikan, yakni dengan adanya pembayaran Retribusi Parkir secara ganda.

2. Bahwa jika dilihat dari teori implementasi kebijakan Donald Van Meter dan Carl Van Horn menegaskan bahwa perubahan, kontrol dan kepatuhan bertindak merupakan konsep-konsep penting dalam prosedur implementasi. Dengan memanfaatkan konsepkonsep tersebut, maka permasalahan yang perlu dikajiialah jumlah masing-masing perubahan yang akan dihasilkan, dan jangkauan atau lingkup komitmen terhadap tujuan diantara para aktor, atau pihak-pihak yang terlibat dalam proses implementasi. 
Artinya, implementasi pada program- program kebijakan publik kebanyakan akan berhasil ketika perubahan yang dikehendaki relatif sedikit. Kemudian dalam teori Maslahah al- Mursalah,sebagai bagian dari produk yang menjadi acuan dalam semangat mengimbangi perkembangan hukum dikalangan masyarakat, menjadi patokan untuk menentukan keberadaan Peraturan Daerah Nomor 12 Tahun 2008 tentang Retribusi Parkir Kendaraan Kabupaten Jember khususnya dalam Retribusi Parkir Berlangganan. Hukum Islam yang mempunyai karakteristik dinamis, dalam arti selalu ada hukumnya ketika terjadi fenomena ataupun hal-hal yang dikira perlu mendapat sebuah legitimasi dalam kehidupan masyarakat, maka Maslahah al-Mursalah yang peneliti ambil sebagai kaca mata dalam menanggapi keberadaan perda tersebut.

\section{Daftar Pustaka}

\section{Buku}

Marzuki, Peter Mahmud. 2005. Penelitian Hukum. Jakarta: Prenada Media Group. Saebani, Beni Ahmad. 2009. Metode Penelitian Hukum. Bandung: CV Pustaka Setia.

Riskiyono, Joko. 2017. Pengaruh Partisipasi Publik dalam Pembentukan Undang-undang. Depok: Nadi Pustaka.

Sufianto, Dadang. 2015. Pengantar Ilmu Pemerintahan. Bandung: CV Pustaka Setia.

Wahab, Abdul. 1994. Khallaf, Ilmu Ushul Figh. Semarang: Dina Utama.

\section{Jurnal dan Skripsi}

Haerah, Kahar. Kontribusi Penerimaan Retribusi Parkir Terhadap Pendapatan Asli Daerah Kabupaten Jember. Jurnal Politico Vol 18, No 1 Maret 2018.

Mafruki, Muhamad. 2017. Respon Masyarakat Kota Malang Terhadap Peraturan Daerah Kota Malang Nomor 3 Tahun 2015 Tentang Retribusi Jasa Umum Prespektif Maslahah Mursalah. Malang: Skripsi Universitas Islam Negeri Maulana Malik Ibrahamim Malang.

\section{Perundang-undangan}

Undang-Undang Nomor 12 Tahun 20011 tentang Pembentukan Peraturan Perundangundangan.

Peraturan Daerah Nomor 12 Tahun 2008 tentang Retribusi Parkir Kendaraan Kabupaten Jember.

\section{Laman}

https://nasional.tempo.co/read/153142 